\title{
To syke professorer i et galehus
}

Vi var to professorer som satt i hvert vårt hjørne av den ærverdige, gamle bygningen som tidligere huset stedets asyl. Gedigne vinduer med dype karmer ga oss en eventyrlig utsikt, og når solen viste seg, syntes vi begge at vi var kommet på rett plass. Det var bare det at vi til stadighet nøs. Nysene pleide å komme i serier - tårene haglet og nesen fløt over av blank væske.

Flere år tidligere hadde jeg bemerket at det luktet sopp i bygningen. Dette skjedde forut for at lokalene ble pusset opp i 1998. De hadde da stått tomme i noen år. Verneombud ble koblet inn, men det lyktes oss ikke å få til noen undersøkelse av innemiljøet. Maling ble strøket på veggene og et nytt ventilasjonsanlegg installert.

Det var bare det at vi til stadighet nøs. Vi kontaktet da arbeidsmedisinsk avdeling og bedriftslege, men prøvene av inneluften viste ikke noe galt, bortsett fra høy luftfuktighet $\mathrm{og}$ dårlig ventilasjon.

\section{Sopp}

Så kom dagen da en av oss flyttet et løst garderobeskap. På veggen bak var det et tilnærmet rundt, gråsvart område så stort som en festballong. Den nypåførte malingen var her gjennomtrukket av en svart masse. Det luktet surt og gammelt. Et tilsvarende område ble avdekket bak en radiator på kollegaens kontor-på den samme veggen, som vendte mot sør.

Da kom yrkeshygienikerne på banen igjen, og synderne ble identifisert: På det ene kontoret ble det $\mathrm{i}$ det vesentlige funnet Cladosporium, på det andre ble det funnet sporer både av Penicillium, store mengder Zygomyceter, Alternaria alternata, Chaetomium samt Strachybotus catharum. Alle er helseskadelige som allergener. Dessuten kan noen av dem fremkalle hypersensitiv pneumonitt og gi toksiske skader (1).

Min kollega og jeg hadde sittet i soppinfiserte rom i fem år, og skyhøye IgE-verdier ble påvist hos oss begge. Vi fikk en grundig allergologisk utredning, inklusive forsøksvis innsprøyting av antigener fremstilt av de påviste sopparter. Men dette slo ikke ut, muligens som følge av vansker med fremstilling av allergenet. Det viste seg også at vi hadde en ulik allergisk profil, hvilket kunne ha sammenheng med at det var forskjellige soppkolonier som ble funnet på de to kontorene.

Kontorene ble sommeren 2003 grundig renovert og «sterilisert». Det ble bygd nye «falske» innervegger på omkring en tredels meters tykkelse langs ytterveggene. Dette reduserte størrelsen på våre deilige kontorer, men det skulle være trygt å oppholde seg der.

\section{Var det en sammenheng?}

Etter renoveringen gikk de forhøyede IgEverdiene for en av oss betydelig tilbake over tid, og det ble mindre nysing. Vedkommende hadde negativ respons på prikktest for muggsopp, mens derimot serumverdiene for D1 Pteronyssimus var sterkt forhøyet (6,2 i juni 2003), for deretter å falle gradvis til dagens nivå $(0,8)$. For den andre av oss har derimot IgE-verdiene holdt seg på omtrent samme nivå. Her var muggsopptesten initialt positiv for Cladosporium, som ble identifisert i store mengder på vedkommendes kontor.

Fem år etter renoveringen har imidlertid begge kroniske plager, særlig fremtredende for den ene. De består av tetthet i nesen samt nysing ved ulike stimuli. Plagene oppstår for As vedkommende bare på kontoret, til tross for at inneluften nå ikke viser økte mengder sopp. B har de samme plager som A pluss en tendens til langvarige luftveisinfeksjoner, og her utløses symptomene også utenfor kontoret.

\section{Ble ikke hørt}

Det som bekymrer oss, er at vår kliniske teft som helsepersonell med langvarig erfaring ikke ble vektlagt og at gjentatte beskjeder til huseier ikke nådde frem. Og det som gjorde det ekstra vanskelig, var uklarhetene omkring hvem som hadde det økonomiske ansvaret for oppussing og vedlikehold av lokalene - eier av bygningen var helseforetaket, mens universitetet var vår arbeidsgiver. Dette gjelder nok dessverre mange av våre helseinstitusjoner og fører til et utmattende byråkrati hvor begge parter fraskriver seg ansvar. Det bekymrer oss videre at man hittil ikke har lyktes med å bedre ventilasjonsforholdene i lokalene. Ulike myndigheter slåss fortsatt mot hverandre - ettersom ingen vil dekke utgiftene. Endelig bekymrer det oss at offentlig bygningsmasse generelt forfaller - ikke bare sykehus, det gjelder i like høy grad skoler og kirker.

\section{Syke hus}

Vi ønsker å sette søkelys på et problemområde som antakelig er betydelig mer utbredt enn det som kommer frem i helsestatistikkene. I Sverige har det vært mye debatt både i dagspressen og Läkartidningen om de syke husene og hva disse gjør med menneskene. Fortsatt er det betydelig faglig uenighet om sammenhengen mellom inneklima og helseskader (1), noe vi fikk føling med umiddelbart etter påvisning av soppen.

Noen sopparter produserer også toksiner som har en langt mer omfattende virkning på immunsystemet enn vanlige allergener som pollen. Dette kan gjøre soppen desto mer skadelig (2). «Sick building syndrome» (SBS) består i helseplager som er forbundet med høy luftfuktighet $i$ dårlig ventilerte lokaler hvor sopp ikke er identifisert $(3,4)$. Høy fuktighet og dårlig ventilasjon ble funnet $\mathrm{i}$ våre kontorer både før og etter påvisningen av sopp i veggene. Dette kan således ha vært en egen risikofaktor i tillegg til soppen, eller forsterket skadene frembrakt av soppen.

Vi er blitt påført langvarige plager som sannsynligvis aldri går helt tilbake, til tross for sanering av alle kjente faktorer som vedlikeholder plagene. Et vesentlig poeng er likevel at ingen fulgte oss opp etter at soppskaden ble påvist. Også her ble vi overlatt til oss selv.

Hadde dette hendt i USA, ville vi antakelig ha sittet igjen med en klekkelig erstatning. Vi ønsker imidlertid ikke amerikanske tilstander hva gjelder kompensasjon for helseskader. Derimot ønsker vi oss myndigheter som lytter - både sentrale og lokale myndigheter som tar inneklima og vedlikehold på alvor.

\section{Brit Haver}

brit.haver@psyk.uib.no

Seksjon for psykiatri

Institutt for klinisk medisin

Universitetet i Bergen

Postboks 23 Sandviken

5812 Bergen

Oppgitte interessekonflikter: Ingen 
Litteratur

1. Bush RK, Portnoy JM, Saxon A et al. The medical effects of mold exposure. J Allergy Clin Immunol 2006: 117: 326-33.

2. Simon-Nobbe B, Denk U, Poll V et al. The spectrum of fungal allergy. Int Arch Allergy Immunol 2008; 145: 58-86.
3. Björnsson E, Janson C, Norbäck D et al. Symptoms related to the sick building syndrome in a general population sample: associations with atopy, bronchial hyper-responsiveness and anxiety. Int J Tuberc Lung Dis 1998: 2: 1023-8.

4. Bakke JV, Wieslander G, Norback D et al. Atopy, symptoms and indoor environmental perceptions, tear film stability, nasal patency and lavage biomarkers in university staff. Int Arch Occup Environ Health 2008; 81: 861-72.

Manuskriptet ble mottatt 15.8. 2008 og godkjent 6.5. 2009. Medisinsk redaktør Trine B. Haugen.

\section{Kommentar}

\section{Når huset er sykt}

Da jeg leste historien til de to professorene som hadde opplevd plager pga. inneklimaet på jobben, slo det meg at dette har jeg hørt før. Mange ganger! Nå kjenner jeg ikke detaljene i denne aktuelle saken og kan ikke uttale meg om den. Det jeg kjenner til, er at liknende historier ikke er så uvanlige. Dette bekreftes av overlege Ebba Wergeland i Arbeidstilsynet, som forteller at det kommer mange meldinger fra leger om luftveisplager hos ansatte som arbeider i lokaler med fuktskader. Hun forteller at disse sakene tar påfallende lang tid. Det går gjerne måneder og år fra fuktskader oppstår, eller fra folk blir syke, til noe blir gjort (1).

\section{Hva vet vi om fuktskader?}

Litteraturen viser at det er sammenheng mellom fuktskader i hus og plager fra luftveiene $(2,3)$. Et fuktskadet arbeidslokale gir sykdomsrisiko, men hvilke mekanismer vi her står overfor, er uklart. Det er ikke så enkelt som at man kan måle soppsporer eller bakterier og finne spesifikke allergier. Ofte finner man ingenting unormalt ved målinger, verken i miljøet eller i kroppen. Grunnen er at de metodene vi har, er for dårlige (4). Vi vet ikke hvilke forurensninger som er årsaken til plagene for mennesker i fuktskadede hus, og ikke hva og hvordan vi skal undersøke.

\section{Hva vi bør gjøre, og hva som faktisk skjer}

Et fuktskadet arbeidslokale skal saneres enten folk er blitt syke av å være der eller ikke. Slik sanering står beskrevet allerede i 3. Mosebok (5), og dette burde snart bli forstått. Sommel med sanering av fuktskader kan være svært skadelig for de ansatte. Vi skal videre undersøke miljøet for å finne ut omfanget av problemet, og vi skal undersøke de involverte arbeidstakere grundig. Det vi ikke skal gjøre, er å ta mål av oss til å sammenholde miljøfunn med eventuelle helseplager og vente med å informere og gi råd til arbeidsgiver og huseier før dette er helt på plass. Vi kan ikke forvente å finne konsistente sammenhenger mellom miljøfunn og f.eks. immunologiske funn siden kunnskapsnivået vårt er så dårlig. Det er ofte her feilen skjer. Pasient og miljø utredes i det uendelige, mens man burde ha satt i gang saneringen umiddelbart der fuktskader er påvist.

\section{$\emptyset$ konomi og lovverk}

Det kan være vanskelig å få gjennomslag for sanering av fuktskadede hus, da slike tiltak koster penger. Der arbeidsgiver leier lokalene, kan det fort bli forsinkelser i saneringsprosessen pga. uklar kommunikasjon med eier. Arbeidsgiver har ansvar for å ta kontakt med huseier og få sanering utført. Hvis ikke dette er mulig innen kort tid, skal de ansatte ha nye lokaler. Her kan man støtte seg til arbeidsmiljøloven. Den har som målsetting å sikre et arbeidsmiljø som gir full trygghet mot fysiske og psykiske skadevirkninger.

\section{Kommer vi noen gang videre?}

Vi må ha et skarpere søkelys på inneklimaproblemer. De fleste nordmenn sitter innendørs og arbeider, og saken burde være av interesse for de fleste. Imidlertid ser det ut til at vi i dag er mer opptatt av hvordan isbjørn og ulv har det enn av våre egne miljøforhold. Interesseområdet bør utvides, og vi trenger flere midler til forskning og kompetanseutvikling om inneklima og helse.

\section{Bente Moen}

bente.moen@isf.uib.no

Institutt for samfunnsmedisinske fag

Universitetet i Bergen

Kalfarveien 31

5018 Bergen

\section{Oppgitte interessekonflikter: Ingen}

\section{Litteratur}

1. Wergeland E. Uproff håndtering av fuktskader. Arbeidervern 2005; 1: 6

2. Bornehag CG, Blomquist G, Gyntelberg F et al. Dampness in buildings and health. Indoor Air 2001; 11: 72-86.

3. Bornehag CG, Sundell J, Bonini S et al. Dampness in buildings as a risk factor for health effects, EUROEXPO: a multidisiplinary review of the litera ture (1998-2000) on dampness and mite exposure in buildings and health effects. Indoor Air 2004; 13 243-57.

4. Eduard W. Måling av sopp i luften fra fuktige bygninger - til hvilken nytte? Arbeidervern 2001: 6: 7 .

5. 3. Mos $14,35-48$

Manuskriptet ble mottatt 12.5. 2009 og godkjent 12.5. 2009. Medisinsk redaktør Trine B. Haugen. 